Vladimir A. Koksharov

Berik K. Dzhamanbalin
Ural State University of Railway Transport, Ekaterinburg, Russia Ural Federal University named after the first President of Russia Boris N. Yeltsin, Ekaterinburg, Russia

\title{
Strategic assessment of electric power industry development: A case of Kazakhstan
}

\begin{abstract}
Despite the stability of Kazakhstan's economy there is a need for objective and comprehensive research into the problems of the country's electric power industry management. The study aims to identify priority problems hindering electric power industry development in Kazakhstan based on modelled strategic assessments. The methodological basis of the research includes the concepts of strategic management applied at a macrolevel. In terms of the methods the authors rely on the multidimensional ranking procedure, which allows setting priorities for the industry development in compliance with the key objectives of the country. The proposed methodological framework for identifying the priority problems aims to improve the quality of the considered stage of devising strategic plans for the industry development. It has to firstly, make the selection of the main problems faced by the industry more objective; secondly, standardise and formalise the selection procedure as much as possible, i.e. adapt it for application not merely in the electric power industry, but in all other major sectors of the economy. The results of the research confirm that the proposed model linking the electric power industry development and the country's economic growth and competitiveness is of practical use.
\end{abstract}

Keywords: dynamic normal; competitiveness; power consumption; energy intensity; energy saving; energy efficiency.

For citation: Koksharov V. A., Dzhamanbalin B. K. Strategic assessment of electric power industry development: A case of Kazakhstan. Journal of New Economy, 2019, vol. 20, no. 4, pp. 119-132. DOI: 10.29141/2073-1019-2019-20-4-7

Received February 26, 2019.

\section{Introduction}

$\mathrm{K}$ azakhstan's economy industrialisation that involves the development of energy-intensive industries causes problems for the electric power industry. In this regard, it is particularly important to define priority problems to achieve sustainable and competitive development of the country's economy. However, currently applied methods have flip sides making such prioritisation impossible. The main deficiencies are as follows:

- effectiveness of the organisational and financial form of the industry is determined by external factors independent of the industry [Pfantsagl, 1976; Rakitskiy, Ustinov, Chernorutskiy, 1979];

- complicated and time-consuming decision-making [Klyuev, 2018];

- each problem has to be expressed through some final industrial criterion with respect for the importance of all other criteria included while, at the same time, it is difficult to reduce all models to the target function in an unbiased manner [Makarov et al.,1984; Melentev, 1982; Okorokov, 1976; Padalko, 1979; Tsisar, Neyman, 2002; Kendall, 1955];

- traditional methods of expert assessment cannot correlate the problems of the industry directly with the country's objectives [Pfantsagl, 1976; Rakitskiy, Ustinov, Chernorutskiy, 1979]; 
- reliance on comparing the variation series suggested by different experts [Mirkin, 1974; Suppes, Zinnes, 1967; Syroezhin, 1980] ${ }^{1}$.

Economic theory [Germeyer, 1971; Dukenbaev, 1998; Kornyakov, 2000; Revenkov, 2001; Fraser, 1999] suggests that the degree to which the state and the private sector are involved in the administration generally affects the competitive environment created in the industry and in the country.

From such a perspective, the study aims to develop a fundamentally new methodological approach to assess the priority problems of electric power industry development.

The authors assume that hypotheses are necessary to be formulated to prove that the assessment of priority problems faced by the electric power industry can help identify the interconnections in the fields of energy efficiency, energy saving, environmental protection, and market relations between energy producers and consumers in order to ensure economic growth and competitiveness of the country; develop and test a framework for carrying out a dynamic assessment of the electric power industry development strategy.

The scope of the questions raised in connection with the purpose of the study included the following:

- how to provide energy services at a reasonable price to ensure the sustainable development of the economic sectors;

- what are the ways to improve energy efficiency in all sectors of the country's economy;

- how to reduce harmful impact of the greenhouse gases and other waste of energy production on the environment;

- what are the ways to increase reliability of electric power supply, energy security, and energy policy prioritisation.

When designing the development strategy for an individual energy provider, it should be taken into account: a. the problems of the country and the industry as a whole; b. the possibility of optimising the financial and organisational structure of the enterprises in the industry in terms of improving their competitiveness, intensity of innovation, and scale of potential investments.

To make an objective selection of the key final indicators of the region's electric power industry development a number of significant indicators were analysed such as the region's investment attractiveness; competitiveness of a certain group of enterprises (by industry); and scale of innovation [Bobylev, Zakharov, 2011] $]^{2}$. The scale of investment, and a number of other indicators were rejected because they represent a means of solving some more important task. At the state level, there are two of the most critical "conceptual" and, therefore, hardly contestable goals, namely to ensure security (or "sufficient defence capability"); and to raise the standard of living of the country's population. At the regional level, there remains one indisputable goal: to raise the living standards in the region. Of course, the aforementioned means of achieving this goal can and even should be present on the model maps.

As a first step of the methodological approach, the most exhaustive record of industry problems is made using the most comprehensive list of information sources to avoid "gaps" in the problem analysis at the following steps.

To make the selection of industry problems more objective, our first idea is:

- to take into consideration the goals and main problems of the country ("super goals"), i.e. the country should take priority over the industry (at the same time, the traditional methods used to identify the problems faced by the industry are not rejected but serve as a possible

${ }^{1}$ Also refer to: Electricity reform in APEC economies - the way ahead. A review for the APEC Energy Working Group of APEC's. (2003). India: Oxford Institute for Energy Studies.

${ }^{2}$ Also refer to: [Volgin, Kushlina, 2001]. 
addition to the proposed approach and, therefore, should be seamlessly integrated into the general selection framework);

- to take account of the industry's organisational goals, especially those related to the interest held in the industry by the state and the private sector;

- to use the existing rating information that is "free" and yet scarcely used to improve the process of management: this particularly concerns the fairly objective world competitiveness rankings (Global Competitiveness Index);

- to use the cognitive mapping technique to correlate the consequences of solving (or not solving) the problems of the industry with the "distant" (by their level in the governing hierarchy) super-goals of the country;

- to provide clear algorithms for all calculations and constructs.

To standardise the problem selection procedure, the second idea is:

- to formalise the interrelations between the goals of the country and those of the industry as much as possible;

- to formalise the interrelations between the problems and organisational objectives of the industry as well as between the problems of the industry and its organisational and financial form as much as possible (using the elements of graph theory and the theory of expert assessments);

- to provide clear algorithms for all calculations and constructs.

The third idea suggested in the study is to make the selection algorithm of the problems of the industry less complicated by picking out the issues in three successive screening stages. At the first stage, the problems of the industry are arranged in order of priority from the perspective of one of the most important economic goals of the country, namely the competitiveness. At the second stage, the previously selected problems are sorted by importance in the context of the set of closely related goals of the industry (this set of goals is closely related to the organisational and financial form of the industry's operation). At the third stage, part of the problems picked out before (especially when the effects of their solving or not solving are ambiguous) pass through another filter and are ranked by the strength of their influence on the ultimate, top-level goals of the country.

Thus, the three consecutive selection filters are arranged, firstly, in the order of ascending labour intensity of selection procedures and, secondly, in a way that allows for consecutive decrease in the range of the selection to avoid unnecessary work when using the entire selection algorithm.

\section{Hypotheses underlying the conceptual approach}

Based on previous research and propositions, we formulate the following hypothesis to be tested.

H1: There is a rational relationship between the assessment of the problems faced by the electric power industry and the economic growth and improvement of the living standards within the framework of the proposed conceptual approach.

Energy supply, its ability to meet social needs, production efficiency, and the cost of energy and fuel are the most important prerequisites and drivers of economic growth in general and the progress of productive forces in particular. Energy supply is the most important factor in environmental management, especially where it is associated with the development of non-renewable resources and condition of the living environment. From this perspective, primary energy problems of the electric power industry development can be quite legitimately classified as crucial which require an effective solution to ensure the country's economic growth and competitiveness. However, the study of these energy problems needs to be specific and take into account the level of development of the productive forces, social relations, and specificity of the interrelation between energy supply and economic growth in its various types and at different stages [Barkin et al., 2014]. 
Such an approach allows us to properly distinguish between technical and economic maturation and exacerbation of the electric power industry development problems, and to differentiate their manifestations by individual periods and production industries. It is especially important when analysing problems at the current stage, as it can help evaluate the alternatives for the electric power industry, which undoubtedly has theoretical, political, and practical importance.

In its most general form, the relationship between energy consumption and economic growth is determined by the attained level of production development and the nature of productive relations. The type of economic growth is of considerate importance as well. When it is extensive, propelling new economic resources into production, specific energy consumption tends to grow faster than in the case of intensive growth that generally has a material-saving nature.

Electric power consumption is an important indicator of the quality of life, closely related to the growth rate and structure of the economy. Therefore, by analysing specific electric power consumption by the main sectors of Kazakhstan's economy, we can identify the key factors determining the dynamics of specific electric power consumption in the forecast period. In ferrous metallurgy, growth in electric smelting is compensated by total energy saving; in the aluminum industry, modern plants are built using new technologies, while in other non-ferrous metal industries, total energy saving is compensated by increased added value. In the petroleum refining industry, increased refinery yield and improved quality of petroleum products increase specific electric power consumption. In the coal industry, growth of energy consumption is due to introduction of new coal washing technologies.

In mechanical engineering, the main factors affecting specific energy consumption include the following. Specific energy consumption is reduced due to the introduction of the new, less power-intensive metal processing technologies. The industry-average savings are estimated at 20-30 \% [Germeyer, 1971]. Specific energy consumption is also reduced as a result of a growing number of assembly plants where energy-intensive assembly is not the main production process, and a significant part of manufacturing is performed in other countries. A larger share of metal-intensive and energy-intensive processing also decreases specific energy consumption of the engineering industry. Such a factor as the rise in the cost of engineering products due to their improved quality, consumer properties, and increasing emphasis on high technology causes the specific energy consumption to fall when calculated as part of the manufactured unit cost [Kendall, 1955].

Global experience demonstrates that economic growth is traditionally accompanied by an increase in electric power consumption [Volgin, Kushlina, 2001]. The relationship between the economic growth rates and electric power consumption is characterised by the elasticity coefficient (increase in electric power consumption by $1 \%$ of the GDP growth) the value of which depends on the nature of development and structure of the economy. The obvious connection between the electric power industry and economic growth is forcing the developing countries to increase their energy assets [Barkin et al., 2014]. The main factor behind the growing demand for electricity is the growth of industrial production [Vaynzikher, 2008].

Based on previous research, we formulate the following hypothesis to be tested:

H2: There is a rational relationship between the assessment of the problems faced by the electric power industry and the shortage of energy resources, economic growth, and competitiveness of a country within the framework of the proposed conceptual approach.

Today, there are the problems in the electric power industry that affect the sustainable economic development of Kazakhstan and hamper the country's competitiveness on the global market:

- lack of energy resources and electricity;

- threat of environmental pollution due to human impact of electric power facilities; 
- choice of a business model for the electric power industry operation.

The first problem relates to the fact that today's main energy resources are non-renewable, and are unevenly distributed across Kazakhstan. There are two ways to ensure energy security.

The first way is to search and develop domestic non-renewable and renewable energy resources. Incredible as it may seem, the energy-abundant states may also face problems with energy resources, as there is a real opportunity to live off the resource rent. There is every reason for this, as the volume of oil production is planned to be increased to 107.3 million tonnes by 2025 , and gas production - to 77.3 billion $\mathrm{m}^{3}$. The annual oil refining output will be increased to about 17 million tonnes to ensure production of petroleum products per environmental standards. In terms of potential coalbed methane resources, Kazakhstan is among the top ten countries in the world. Upon completion of exploration and appraisals, gas reserves will be placed on the state balance sheet. Strategic importance of having this problem assessed suggests the following approach.

The Caspian Pipeline Consortium's Oil transport expansion project has been completed in Kazakhstan with the participation of Russia, Kazakhstan, and leading mining companies. The pipeline transporting more than two thirds of Kazakhstan's total oil exports stretches for $1,511 \mathrm{~km}$.

In Kazakhstan, more than $70 \%$ of gas is produced by foreign investors from the United States, China, Russia, and the EU countries represented by large national and transnational companies such as ExxonMobil, Chevron, BP/Statoil, Shell, Total, INPEX, Philips, LUKOIL, and others.

There is an overall positive trend in the target indicators of gas production, considering the scheduled geotechnical efforts taken to increase gas production and expand associated petroleum gas processing capacity. One of the promising areas of gas industry development is advanced gas processing intended to produce gas chemical products with high added value.

The second way is to improve energy saving and energy efficiency, since energy-deficient countries are forced to spend a significant part of GDP to purchase energy resources, which has a negative effect on the economy and social sphere. Implementation of this method involves the following.

The objectives set in the Strategic plan for development of the Republic of Kazakhstan until the year 2020 and the Concept for transition of the Republic of Kazakhstan to Green Economy are intended to reduce the energy intensity of the country's GDP by $25 \%$ by 2020 and at least twice by 2050 (relative to 2008). As of the end of 2017, the country's energy intensity of the GDP has been reduced by $18 \%$ compared to 2008 .

In 2016, the World Bank performed an assessment of government regulation of energy efficiency across 111 countries. The Republic of Kazakhstan ranked the 32nd. By 2020, the country plans to improve its performance by $25 \%$, and then Kazakhstan will be able to enter the top thirty countries, and reach the top twenty by 2050, if it doubles its performance. According to the survey performed by the International Energy Agency, Kazakhstan ranks the 119th out of 143 countries by energy intensity of GDP. At the same time, Kazakhstan's GDP energy intensity is twice as high when compared to the world average and four times as high when compared to the OECD member countries; among the CIS countries, Kazakhstan ranks the fifth.

The basis of the modern energy saving system was formed in 2012-2015 as part of the first five-year period of industrial innovative development of Kazakhstan. Taking the experience of Japan into account, the State Energy Register has been created as a key element of the energy saving system. It currently includes more than 5,000 organisations. In 2016, the Ministry of Investment and Development of the Republic of Kazakhstan started to digitise energy efficiency indicators by setting up the Automated Information System of the State Energy Registry. In 2018, the system was launched in pilot mode, and $40 \%$ of all the members of the State Energy Registry provided information in the electronic form. The system is planned to be enshrined 
at the statutory level. The energy efficiency measures taken have already stabilised the level of energy intensity in the country (Fig. 1).

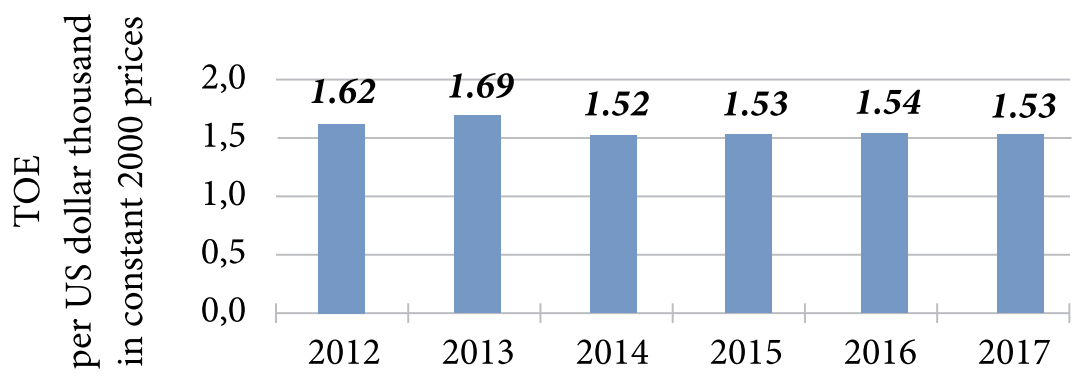

Fig. 1. The energy intensity of the Republic of Kazakhstan's GDP,

TOE per US dollar thousand in constant 2000 prices $^{1}$

Рис. 1. Энергоемкость ВВП в Республике Казахстан, т.н.э. на тьс. долл. США в ценах 2000 г.

It is self-evident that the lack of energy resources will be a deterrent to the country's economic growth, as, to deliver the production target per sector of the economy, plant capacities will either be underloaded or will fail to meet the demand. Therefore, the economies of scale will not reach their fullest potential, which will affect the cost of products and services, and this in turn will impact the competitiveness. Most experts believe that, under any anticipated scenario of the electric power industry development, the problem of meeting the growing demand for fuel and energy at reasonable prices and with minimal damage to the environment can be dealt with by implementing the concepts of energy saving and energy substitution, coupled with both building up the use of traditional fuels and involvement of alternative fuel resources into the energy production. The energy saving concept is implemented through the more efficient handling of the energy resources at all stages of their lifecycle: prospecting - survey - electrical and thermal energy production - transportation to consumers - consumption. At the same time, the presumption is that the existing problems of the electric power industry development will distort the pattern of economic growth and competition and cause a decrease in the industry efficiency.

Based on previous research, we formulate the following hypothesis to be tested.

H3: There is a rational relationship between the assessment of the problems faced by the electric power industry and the threat of environmental pollution due to the human impact created by electric power facilities, the economic growth, and the country's competitiveness within the framework of the proposed conceptual approach.

The second problem, which is of the environmental concern, progresses with the growing scale of the electric power industry development, and this scale and the technologies applied lead to the fact that $50 \%$ of the man-made emissions into the atmosphere come from electric power facilities. The government of Kazakhstan is taking the following organisational and economic steps: it cooperates with the European Bank for Reconstruction and Development on investments in renewable sources of energy. The bank has an opportunity to support the economy of Kazakhstan by supplying the investments and advising the authorities on economic reforms. The bank has invested about half a billion euros over the period of its operation in Kazakhstan. $57 \%$ of investments under 17 projects it has implemented in Kazakhstan were targeted at developing green economy in the country.

The Government of Kazakhstan has sent a national application to the UN Green Climate Fund. If approved, it will ensure the country's access to the fund's resources to attract finance

${ }^{1}$ Source. Energy intensity of the processing industry in the Republic of Kazakhstan. Available at: http://comprom.miid.gov.kz/ru/pages/energoemkost-obrabatyvayushchey-promyshlennosti-respubliki-kazahstan. (in Russ.) 
to the country through such tools as green bonds, green loans, green insurance, and green purchases. The fund provides financial support to promoting the transition to the principles of sustainable green development in various sectors of economy. Kazakhstan submitted a 280 million US dollar application. As of January 1, 2017, consolidated recoverable reserves of liquid hydrocarbons amounted to 785.8 million tonnes, while the increment of oil and gas condensate reserves in 2016 totalled at 7.2 million tonnes.

Based on previous research, we formulate the following hypothesis to be tested.

H4: There is a rational relationship between the assessment of the problems faced by the electric power industry and the choice of the electric power industry business model and improvement of the country's living standards within the framework of the proposed conceptual approach.

The third problem is the choice of the business model for the electric power industry operation in the market economy. The problem is very complicated, since modern electricity markets are fundamentally different from the classical markets of perfect competition. This can be explained by the organisational and technological features and technical regulations of the industry. There is insufficient amount of modern measuring and control devices on electricity markets allowing for real-time data exchange which is one of the necessary conditions for ensuring free competition.

At present, contradictions are aggravated by insufficient study of the fundamentals of improving the energy companies' competitiveness. Therefore, the problems of transforming the electric power industry's organisational structure become more relevant. Their solution can facilitate establishment of the mechanisms necessary for managing efficiently and developing strategies that would help evaluate and select priority problems faced by the electric power industry as a source of economic development and a factor of the country's future competitiveness.

The collapse of the USSR predetermined the development of the entire energy sector of Kazakhstan, including the electric power industry. In 1990, Kazakhstan only produced $83.7 \%$ of its electrical demand of 104.7 billion $\mathrm{kWh}$, with the 17.3 billion $\mathrm{kWh}$ balance deficit. In subsequent years, the generating capacities were expanded to add extra rated output of about 8 billion $\mathrm{kWh}^{1}$. The electric power industry of Kazakhstan is a basic sector of the economy awaiting structural and technological changes that will be accompanied by large-scale investments in the state's energy-efficient policy. The main problem of the electric power industry - high equipment deterioration - took shape during the financial crisis, with $65 \%$ of the electric power plant facilities aged over 20 years, and $31 \%$ over 30 years. $90 \%$ of the combined heat and power plant equipment is beyond the end of its useful life. The process of combining the disparate electric power systems of Kazakhstan's regions is currently underway to reduce electricity imports and increase exports and, thus, to optimise the structure of the generating capacities and to cut the cost of electric power generation.

Establishment of the electricity market rests upon the restoration of parallel operation of the electric power systems of Russia and Kazakhstan in order to fully cover the demand for cheap electricity and use the transit potential of the two countries more efficiently. The countries are currently creating interstate vertically integrated structures comprising the whole range of energy services. Reformation of Kazakhstan's electric power industry is intended to:

- create a transparent, verifiable, and efficient electric power supply system with a market price for electricity;

- promote more efficient electricity generation by cutting costs through competition among energy producers;

${ }^{1}$ The current state and prospects of the power industry development in Kazakhstan. Available at: https:// articlekz.com/article /6658. (in Russ.) 
- encourage the generating companies in the market to work with liquid payments and attract investments for their modernisation;

- improve electric power production efficiency through utilising market mechanisms that contribute to a reduction in electricity prices for the end users.

The main goal of the electric power industry reformation in Kazakhstan is to improve the efficiency of the enterprises within the industry, to create conditions for its development by encouraging investments, and to ensure reliable and uninterrupted electric power supply to consumers. In the course of the reform, the structure of the industry is shifting; the system of the state regulation of the industry is changing; the traditionally monopolistic (power transmission, operational dispatch management) and potentially competitive (power generation and sales, repair and service) functions are being separated; conditions for a competitive electricity market are emerging; and new companies are entering the market. However, deregulation of the electricity market does not mean that the state would completely waive its control over this segment of the economy.

Based on the research of the significant interrelations between the estimated problems faced by the electric power industry and the country's economic growth and competitiveness, the final hypothesis can be formulated as follows.

H5: The strategic importance of assessing the problems faced by the electric power industry development determines rational relationships of the conceptual approach in the field of energy efficiency, energy saving, environment, and market relations between energy producers and consumers ensuring economic growth and improvement of the living standards of the population.

\section{Conceptual approach to assessing priority problems}

The author's model for the empirical testing of the suggested hypotheses is shown in Fig. 2.

Based on the above analysis of working hypotheses, the authors propose a conceptual approach that represents the strategic pattern of the country's economic growth and competition following a timely solution of priority problems faced by the electric power industry in the framework of market relations as a system of dynamic normals:

$$
(G D P)^{\prime}>(P R)^{\prime}>(S)^{\prime}>(Q)^{\prime}>(\triangle C N)^{\prime}>(C N)^{\prime}>(C S)^{\prime}>(F)^{\prime}>\left(T_{e m}\right)^{\prime},\left(C_{2}\right)^{\prime} .
$$

The GDP growth rate and the growth rate of profit from the sale of electricity to consumers $(P R)^{\prime}$ take the first and the second place respectively. The growth rates of electricity sales $(S)^{\prime}$, and secondary energy use by consumers $(Q)$ ' rank the third. The fourth place is given to the growth rate of the savings of fuel and energy consumption among consumers $(\triangle C N)^{\prime}$ and the growth rate of fuel and energy consumption among electric power producers $(C N)^{\prime}$, which in turn is ahead of the growth rate of energy supply costs $(C S)^{\prime}$ followed by the growth rate of fuel supply $(F)^{\prime}$ to the country's electric power producers [Koksharov, 2015]. Finally, there is the growth rate of the total harmful emissions into the atmosphere of the country from fuel combustion at electric power facilities $\left(T_{e m}\right)^{\prime}$ and the growth rate of emissions $\mathrm{CO}_{2}-\left(\mathrm{CO}_{2}\right)^{\prime}$, which is possible if the required level of environmental safety and rational fuel consumption is ensured through current standards.

Such balance of the growth rates of the proposed indicators is known among scientists as a "decoupling effect" [Bobylev, Zakharov, 2011]. The "decoupling effect" refers to an economy where the GDP growth rate outruns that of the energy resource consumption. This effect is achieved in all developed countries of the world. For example, Denmark has doubled its GDP over the past three decades, while maintaining its energy consumption unchanged [Abboud, 2007]. The outperforming rates of energy saving and renewable energy consumption in 


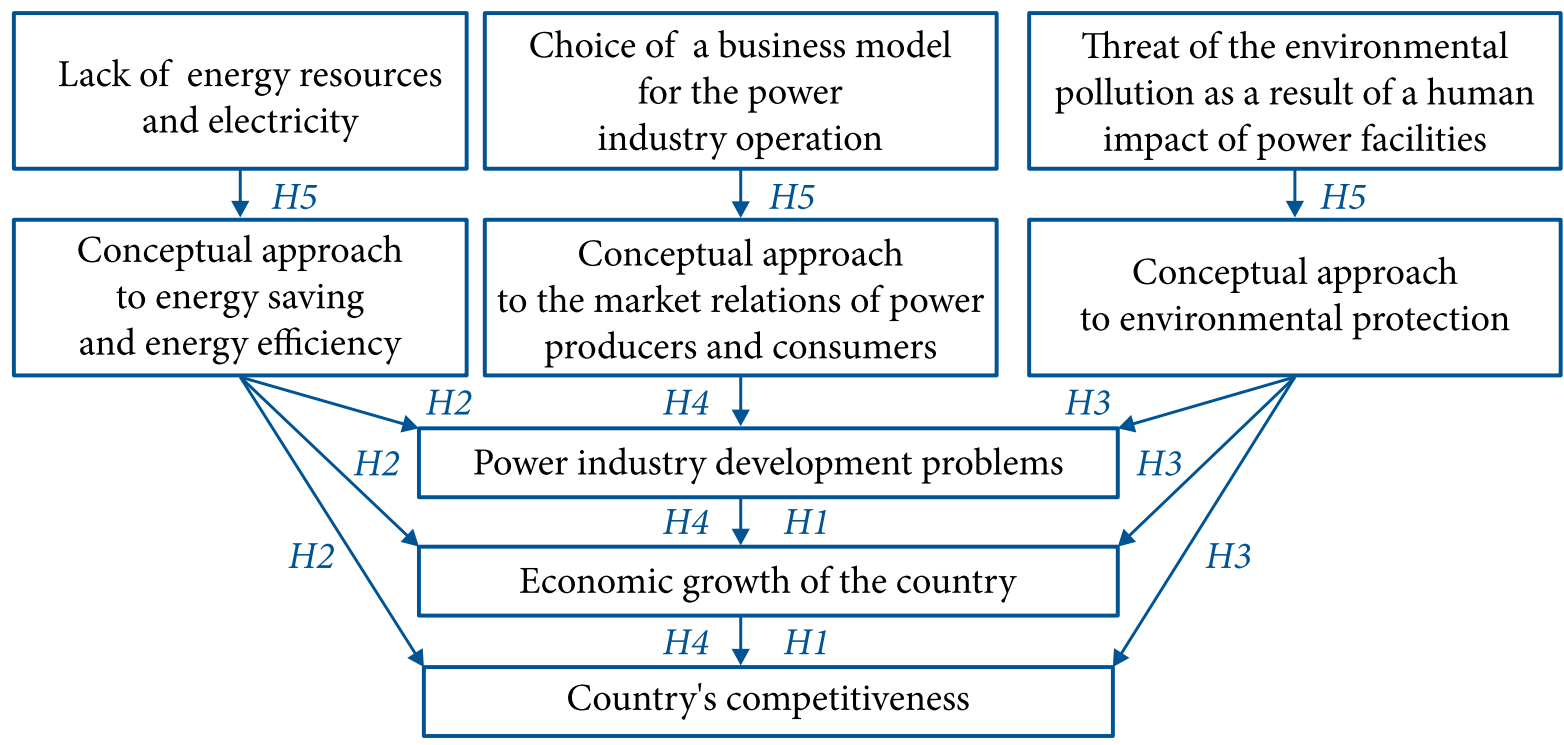

Fig. 2. The general theoretical model considering rational relationships between the problems faced by the electric power industry and the country's economic growth and competitiveness

Рис. 2. Общая теоретическая модель, учитывающая рациональную взаимосвязь проблем развития электроэнергетики с экономическим ростом и конкурентоспособностью страны

production processes are the factors that reduce the growth of total harmful emissions from fuel combustion $\mathrm{CO}_{2}$.

Assessment of the electric power industry strategic development using the dynamic normals is calculated by the equation:

$$
Q_{D}=1-\frac{n}{m}
$$

where $n$ is the number of indicators that changed their position in the actual sequence of growth rates as compared to the normal one; $m$ is the number of pairs of dynamic normal indicators or its derivatives.

The closer the assessment value is to unity, the more the electric power industry development strategy corresponds to the country's economic growth and competition within the framework of the proposed dynamic normals. The proposed conceptual approach is based on the systems approach that allows the electric power industry to be viewed as a system the operation of which is determined by the movement of resources and production waste represented by the ratio of dynamic normal. This allows the measures to be timely taken to eliminate the deficiencies in the electric power industry development.

Open market experience has led to realisation that competitive environment created in generation and sales sectors contributes to the self-regulation of production processes. At the same time, electricity will be priced within the framework of the market system. In order to monitor the problems of the electric power industry development, it is necessary to analyse dynamic normals and identify in a timely manner any negative trends in the strategic pattern of the country's economic growth and competitiveness.

For example, several irrational growth rate ratios characterising a number of problems faced by the country's electric power industry are presented in Table 1.

From Table 2 it can be seen that the "decoupling effect" is absent, since consumption growth rates are higher than those of Kazakhstan's GDP and development indicators of a number of leading sectors of the economy. 
Table 1. Formalised problems of the electric power industry development

Таблица 1. Формализованнье проблемы развития электроэнергетики

\begin{tabular}{|c|c|c|c|}
\hline \multicolumn{2}{|c|}{ Growth rate ratios } & \multirow{2}{*}{$\begin{array}{l}\text { Electric power industry } \\
\text { development problem }\end{array}$} & \multirow{2}{*}{ Impact of the unsolved problem } \\
\hline Rational & Irrational & & \\
\hline$(P R)^{\prime}>(\triangle C N)^{\prime}$ & $(P R)^{\prime}<(\Delta C N)^{\prime}$ & $\begin{array}{l}\text { Energy policy implemented with } \\
\text { no rational communication be- } \\
\text { tween producers and consumers }\end{array}$ & $\begin{array}{l}\text { Rise in tariffs and inconsistency } \\
\text { between energy saving and energy } \\
\text { consumption }\end{array}$ \\
\hline$(G D P)^{\prime}>(\Delta S)^{\prime}$ & $(G D P)^{\prime}<(\Delta S)^{\prime}$ & $\begin{array}{l}\text { No decoupling effect, the coun- } \\
\text { try's GDP growth and competi- } \\
\text { tiveness decline }\end{array}$ & $\begin{array}{l}\text { Electrical shortage and inefficient } \\
\text { structure of generating capacities, } \\
\text { low tax revenues, and rise in tariffs }\end{array}$ \\
\hline
\end{tabular}

Table 2. Indicators of the Republic of Kazakhstan's economic development in 2017-2021

Таблица 2. Показатели экономического развития Республики Казахстан на 2017-2021 гг.

\begin{tabular}{|l|c|c|c|c|c|c|}
\hline \multirow{2}{*}{ Indicator } & \multicolumn{3}{c|}{ Estimates } & \multicolumn{3}{c|}{ Forecast } \\
\cline { 2 - 8 } & 2016 & 2017 & 2018 & 2019 & 2020 & 2021 \\
\hline GDP, billion tenge & $44,354.0$ & $48,391.8$ & $51,690.6$ & $55,280.2$ & $59,611.2$ & $63,643.9$ \\
\hline Actual GDP growth, \% on the previous year & 100.5 & 101.9 & 102.1 & 102.7 & 102.9 & 103.1 \\
\hline $\begin{array}{l}\text { GDP, billion US dollars at the official } \\
\text { exchange rate }\end{array}$ & 123.2 & 134.4 & 143.6 & 153.6 & 170.3 & 187.2 \\
\hline GDP per capita, US dollars & $6,946.9$ & 7483.6 & $7,897.1$ & $8,348.3$ & $9,158.6$ & $9,962.0$ \\
\hline Industrial growth, \% on the previous year & 98.3 & 102.8 & 101.8 & 102.7 & 101.9 & 101.1 \\
\hline $\begin{array}{l}\text { Supply of electric power, gas, steam, } \\
\text { and air conditioning, \% on the previous year }\end{array}$ & 100.6 & 108.0 & 107.0 & 107.0 & 106.0 & 106.0 \\
\hline $\begin{array}{l}\text { Processing industry growth, } \\
\text { \% on the previous year }\end{array}$ & 100.0 & 101.2 & 102.0 & 103.0 & 102.2 & 102.2 \\
\hline
\end{tabular}

Note. Compiled using: Energy intensity of the processing industry in the Republic of Kazakhstan. Available at: http://comprom.miid. gov.kz/ru/pages/energoemkost-obrabatyvayushchey-promyshlennostirespubliki-kazahstan. (in Russ.)

The situation shown in Table 2 is caused by the following factors. The country's industry accounts for $30 \%$ of the total GDP and includes such energy-intensive industries as mining and non-ferrous metallurgy. Kazakhstan consumes 25-30 \% more fuel to produce one unit of energy than developed countries. The main reasons are deteriorated equipment and low efficiency of production processes. Electric power industry is accountable for more than $80 \%$ of the total greenhouse gas emissions.

\section{Conclusion}

The autors' model for evaluating the strategy for the electric power industry development based on the system of dynamic normals is comprehensive and can help identify emerging priority problems faced by the industry development and take measures to eliminate them in a timely manner.

The proposed conceptual approach to identifying priority problems in the electric power industry development is based on the working hypotheses that can be used to determine critical indicators for assessing the country's economic growth and competitiveness and, therefore, to make important management decisions at the level of economic sectors. Analysis of the present conditions for the industry development demonstrates the demand for the proposed integrated approach, which reflects the importance and complexity of the process of building market relations in the electric power industry. 


\section{References}

Barkin O. G., Volkova I. O., Kozhukhovskiy I. S., Kolesnik V. G., Kosygina A. V., Lazebnik A. I., Sorokin I. S., Yasin E. G. (2014). Russian power industry: Problems of choosing the model for development. Analytical report. XV Aprelskaya Mezhdunarodnaya nauchnaya konferentsiya po problemam razvitiya ekonomiki i obshchestva [15th Int. Sci. Conf. on the Problems of Economic and Social Development]. Moscow: Vysshaya shkola ekonomiki Publ. 45 p. (in Russ.)

Bobylev S. N. Zakharov V. M. (2011). Modernizatsiya ekonomiki i ustoychivoe razvitie [Modernisation of economy and sustainable development]. Moscow: Ekonomika Publ., 295 p. (in Russ.)

Germeyer Yu. B. (1971). Vvedenie $v$ teoriyu issledovaniya operatsiy [Introduction to the theory of operations research]. Moscow: Nauka Publ. 384 p. (in Russ.)

Volgin N. A., Kushlina V. I. (eds.) (2001). Gosudarstvennoe regulirovanie rynochnoy ekonomiki [State regulation of the market economy]. Moscow: Ekonomika Publ. 229 p. (in Russ.)

Dukenbaev K. D. (1998). Energetika Kazakhstana. Dvizhenie k rynku [Power industry of Kazakhstan. Transition towards the market]. Almaty: Galym Publ. 584 p. (in Russ.)

Klyuev Yu. B. (2018). Tseli i sredstva ekonomicheskogo razvitiya Rossii v kontekste perekhoda $\mathrm{k}$ shestomu tekhnologicheskomu ukladu [Goals and means of Russia's economic development under the sixth technological wave]. Izvestiya Uralskogo gosudarstvennogo ekonomicheskogo universiteta $=$ Journal of the Ural State University of Economics, vol. 19, no. 6, pp. 33-50. DOI: 10.29141/2073-1019-2018-19-6-3. (in Russ.)

Koksharov V. A. (2015). Upravlenie energopotrebleniem promyshlennogo predpriyatiya [Managing energy consumption of an industrial enterprise]. Ekaterinburg: UrGUPS Publ. (in Russ.)

Kornyakov V. (2000). Gosudarstvenno-korporativnoe napravlenie razvitoy ekonomiki [Statecorporate direction of economic development]. Ekonomist $=$ Economist, no. 5, pp. 74-80. (in Russ.)

Makarov A. A., Kononov Yu. D., Krivorutskiy L. D., Makarova A. S., Saneev B. G., Shapot D. V. (1984). Ierarkhiya modeley dlya upravleniya razvitiem energetiki $i$ metody soglasovaniya ikh resheniy [Hierarchy of models for managing energy development and methods for coordinating their decisions]. Irkutsk: SO AN SSSR Publ., Sibirskiy energeticheskiy institute Publ. (in Russ.)

Melentev L. A. (1982). Optimizatsiya razvitiya i upravleniya bol'shikh sistem energetiki [Optimisation of development and management of big power systems]. Moscow: Vysshaya shkola Publ. 319 p. (in Russ.)

Mirkin B. G. (1974). Problema gruppovogo vybora [The problem of collective choice]. Moscow: Nauka Publ. 256 p. (in Russ.)

Okorokov V. R. (1976). Upravlenie elektroenergeticheskimi sistemami. Tekhniko-ekonomicheskie printsipy $i$ metody [Management of electric power systems. Technical and economic principles and methods]. Leningrad: LGU Publ. 224 p. (in Russ.)

Padalko L. P. (1979). Kriterii i metody optimal'nogo upravleniya elektroenergeticheskoy sistemoy [Criteria and methods for optimal control of an electric power system]. Minsk: Nauka i tekhnika Publ. 198 p. (in Russ.)

Pfantsagl I. (1976). Teoriya izmereniy [Measurement theory]. Moscow: Mir Publ. 248 p. (in Russ.)

Rakitskiy Yu. V., Ustinov S. M., Chernorutskiy I. G. (1979). Chislennye metody resheniya zhestkikh sistem [Numerical methods for solving rigid systems]. Moscow: Nauka. 208 p. (in Russ.)

Revenkov A. (2001). Planirovanie v sisteme gosudarstvennogo reguliro-vaniya ekonomiki [Planning in the system of state regulation of economy]. Ekonomist $=$ Economist, no. 8, pp. 17-21. (in Russ.)

Suppes P., Zinnes Dzh. (1967). Osnovy teorii izmereniy. Psikhologicheskie izmereniya [Basic measurement theory. Psychological measurements]. Moscow: Mir Publ. (in Russ.)

Syroezhin I. M. (1980). Sovershenstvovanie sistemy pokazateley effektivnosti i kachestva [Improving the system of performance and quality indicators]. Moscow: Ekonomika Publ. 192 p. (in Russ.)

Tsisar I. F., Neyman V. G. (2002). Komp'yuternoe modelirovanie ekonomiki [Computer modelling of economics]. Moscow: Dialog-MIFI Publ. 224 p. (in Russ.)

Vaynzikher B. F. (ed.) (2008). Elektroenergetika Rossii 2030: Tselevoe videnie [Russian power industry 2030: Target vision]. Moscow: Al'pina Biznes Buks Publ. 352 p. (in Russ.) 
Abboud L. (2007). How Denmark paved the way to energy independence. Thirty-year plan uses wind, taxes, pig fat; consumers pay more. The Wall Street Journal, 16 April. Available at: https://www.wsj.com/ articles/SB117649781152169507.

Fraser P. (1999). Background report on regulatory reform in the electricity industry. Paris: OECD. 48 p.

Kendall M. G. (1955). Rank Correlation Methods. L.: Griffin and Co. 196 p.

\section{Information about the authors}

Vladimir A. Koksharov, Dr. Sc. (Econ.), Prof. of Transport Economics Dept., Ural State University of Railway Transport, 66 Kolmogorova St., Ekaterinburg, 620034, Russia

Phone: +7 (343) 221-24-41, e-mail: vakoksharov@mail.ru

Berik K. Dzhamanbalin, Postgraduate of Economic Security of Industrial Complexes Dept., Ural Federal University named after the first President of Russia Boris N. Yeltsin, 19 Mira St., Ekaterinburg, 620002, Russia

Phone: +7 (343) 375-41-27, e-mail: pkkstu@mail.ru
В. А. Кокшаров
Уральский государственный университет путей сообщения, г. Екатеринбург, Российская Федерация

Б. К. Джаманбалин Уральский федеральный университет имени первого Президента России Б. Н. Ельцина, г. Екатеринбург, Российская Федерация

\section{Стратегическая оценка развития электроэнергетики Казахстана}

Аннотация. Несмотря на стабильное состояние экономики Казахстана, необходимо объективно и всесторонне исследовать проблемы управления электроэнергетикой страны. Исследование направлено на выявление приоритетных проблем развития электроэнергетики Казахстана на основе стратегических оценок моделирования. Методология исследования представлена концепциями стратегического управления на макроуровне. Методы исследования основаны на процедуре многомерного ранжирования, что позволяет установить приоритеты развития отрасли в увязке с ключевыми целями страны. Методический подход к выявлению приоритетных проблем, направленный на повышение качества рассматриваемого этапа разработки стратегических планов отрасли, должен, во-первых, повысить объективность отбора главных проблем отрасли; во-вторых, максимально унифицировать и формализовать процедуру этого отбора, т. е. приспособить ее к использованию не только отрасли электроэнергетики, но и всех других крупных отраслей экономики. Предложена модель взаимосвязи развития электроэнергетики с экономическим ростом и конкурентоспособностью страны.

Ключевые слова: динамический норматив; конкурентоспособность; электропотребление; энергоемкость; энергосбережение; энергоэффективность. 
Для иитирования: Koksharov V. A., Dzhamanbalin B. K. Strategic assessment of electric power industry development: A case of Kazakhstan // Journal of New Economy. 2019. T. 20, № 4. C. 119-132. DOI: 10.29141/2073-1019-2019-20-4-7

Дата поступления: 26 февраля 2019 г.

\section{Источники}

Баркин О. Г., Волкова И. О., Кожуховский И. С., Колесник В. Г., Косыгина А. В., Лазебник А. И., Сорокин И. С., Ясин Е. Г. (2014). Электроэнергетика России: проблемы выбора модели развития: аналит. докл. к XV Апр. междунар. науч. конф. по проблемам развития экономики и общества. М.: Изд. дом Высшей школы экономики. 45 с.

Бобылев С. Н., Захаров В. М. (2011). Модернизация экономики и устойчивое развитие. М.: Экономика. 295 с.

Гермейер Ю. Б. (1971). Введение в теорию исследования операций. М.: Наука. 384 с.

Государственное регулирование рыночной экономики. (2001) / под ред. Н. А. Волгина, В. И. Кушлина. М.: Экономика. 229 с.

Дукенбаев К. Д. (1998). Энергетика Казахстана. Движение к рынку. Алматы: Галым. 584 с.

Клюев Ю. Б. (2018). Цели и средства экономического развития России в контексте перехода к шестому технологическому укладу // Известия уральского государственного экономического университета. Т. 19, № 6. С. 33-50. DOI:10.29141/2073-1019-2018-19-6-3

Кокшаров В. А. (2015). Управление энергопотреблением промышленного предприятия. Екатеринбург : УрГУПС.

Корняков В. (2000). Государственно-корпоративное направление развитой экономики // Экономист. № 5. С. 74-80.

Макаров А. А., Кононов Ю. Д., Криворуцкий Л. Д., Макарова А. С., Санеев Б. Г., Шапот Д. В. (1984). Иерархия моделей для управления развитием энергетики и методы согласования их решений. Иркутск: СО АН СССР, Сибирский энергетический институт.

Мелентьев Л. А. (1982). Оптимизация развития и управления больших систем энергетики. М.: Высшая школа. 319 с.

Миркин Б. Г. (1974). Проблема группового выбора. М.: Наука. 256 с.

Окороков В. Р. (1976). Управление электроэнергетическими системами. Технико-экономические принципы и методы. Л.: ЛГУ. 224 с.

Падалко Л. П. (1979). Критерии и методы оптимального управления электроэнергетической системой. Минск: Наука и техника. 198 с.

Пфанцагль И. (1976). Теория измерений. М.: Мир. 248 с.

Ракитский Ю. В., Устинов С. М., Черноруцкий И. Г. (1979). Численные методы решения жестких систем. М.: Наука. 208 с.

Ревенков А. (2001). Планирование в системе государственного регулирования экономики // Экономист. № 8. С. 17-21.

Суппес П., Зиннес Дж. (1967). Основы теории измерений. Психологические измерения. М.: Мир.

Сыроежин И. М. (1980). Совершенствование системы показателей эффективности и качества. М.: Экономика. 192 с.

Цисарь И. Ф., Нейман В. Г. (2002). Компьютерное моделирование экономики. М.: Диалог-МИФИ. 224 с.

Электроэнергетика России 2030: Целевое видение (2008) / под общ. ред. Б. Ф. Вайнзихера. М.: Альпина Бизнес Букс. 352 c.

Abboud L. (2007). How Denmark paved the way to energy independence. Thirty-year plan uses wind, taxes, pig fat; consumers pay more. The Wall Street Journal, 16 April. Available at: https://www.wsj.com/ articles/SB117649781152169507.

Fraser P. (1999). Background report on regulatory reform in the electricity industry. Paris: OECD. 48 p.

Kendall M. G. (1955). Rank Correlation Methods. L.: Griffin and Co. 196 p. 


\section{Информация об авторах}

Кокшаров Владимир Алексеевич, доктор экономических наук, профессор кафедры экономики транспорта Уральского государственного университета путей сообщения, 620034, РФ, г. Екатеринбург, ул. Колмогорова, 66

Контактный телефон: +7 (343) 221-24-41, e-mail: vakoksharov@mail.ru

Джаманбалин Берик Кадыргалиевич, аспирант кафедры экономической безопасности производственных комплексов Уральского федерального университета имени первого Президента России Б. Н. Ельцина, 620002, РФ, г. Екатеринбург, ул. Мира 19

Контактный телефон: +7 (343) 375-41-27, e-mail: pkkstu@mail.ru

(C) Koksharov V. A., Dzhamanbalin B. K., 2019 